\title{
PENGARUH INVESTASI DAN PENGELUARAN PEMERINTAH TERHADAP PERTUMBUHAN EKONOMI PROVINSI JAMBI (STUDI TAHUN 2012-2015)
}

\author{
Ambok Pangiuk \\ Fakultas Ekonomi dan Bisnis Islam UIN STS Jambi \\ ambokpangiuk1975@gmail.com
}

\begin{abstract}
Studi ini bertujuan untuk menentukan pengaruh investasi dan pengeluaran pemerintah terhadap pertumbuhan ekonomi Provinsi Jambi dari tahun 2012 sampai tahun 2015. Metode penelitian yang digunakan adalah pendekatan kuantitatif. Sebagai tujuan penelitian diantaranya adalah untuk mengetahui pengaruh investasi terhadap pertumbuhan ekonomi, pengaruh pengeluaran pemerintah terhadap pertumbuhan ekonomi serta pengaruh investasi dan pengeluaran pemerintah terhadap pertumbuhan ekonomi Provinsi Jambi. Berdasarkan penelitian yang dilakukan diperoleh hasil dan kesimpulan sebagai berikut: pertama, bahwa investasi berpengaruh signifikan terhadap pertumbuhan ekonomi Provinsi Jambi, kedua pengeluaran pemerintah berpengaruh signifikan terhadap pertumbuhan ekonomi Provinsi Jambi, ketiga secara simultan investasi dan pengeluaran pemerintah berpengaruh signifikan terhadap pertumbuhan ekonomi Provinsi Jambi, dengan nilai R Square yang diperoleh 0,492, artinya variabel investasi dan pengeluaran pemerintah mempengaruhi pertumbuhan ekonomi Provinsi Jambi sebesar 49,2 \% sedangkan sisanya 50,8 \% pertumbuhan ekonomi Provinsi Jambi dipengaruhi oleh faktor lain.
\end{abstract}

Kata Kunci : Pertumbuban Ekonomi, Investasi dan Pengeluaran Pemerintah

\section{PENDAHULUAN}

Pertumbuhan ekonomi merupakan ukuran atas perkembangan atau kemajuan perekonomian dari suatu negara atau wilayah karena berkaitan erat dengan kegiatan ekonomi masyarakat khususnya dalam hal peningkatan produksi 
barang dan jasa. Peningkatan produksi tersebut kemudian diharapkan dapat memberikan efek yang mampu meningkatkan kesejahteraan masyarakat. ${ }^{1}$

Pertumbuhan ekonomi dalam sistem pemerintahan daerah biasanya di indikasikan dengan meningkatnya produksi barang dan jasa yang diukur melalui Produk Domestik Regional Bruto (PDRB).PDRB didefinisikan sebagai nilai tambah bruto seluruh barang dan jasa yang tercipta atau dihasilkan diwilayah domestik suatu negara yang timbul akibat berbagai aktivitas ekonomi dalam suatu periode tertentu. $^{2}$ Kegiatan ekonomi dalam suatu negara atau wilayah akan optimal jika terdapat aktifitas pemerintah didalamnya, karena pemerintah diberikan kewenangan dalam mengatur pendapatan melalui penarikan pajak pendapatan BUMN, selain itu pemerintah juga diberikan kewenangan untuk membelanjakan anggaran untuk kepentingan masyarakat misalnya memberikan subsidi dan melakukan pembangunan infrastuktur. ${ }^{3}$

Pengeluaran pemerintah merupakan indikator besarnya kegiatan pemerintah, apabila semakin banyak kegiatan pemerintah maka semakin besar pula pengeluaran pemerintah yang bersangkutan, namun ini bukanlah berarti bahwa pengeluaran pemerintah harus selalu ditingkatkan tanpa memperhitungkan aspek efisiensinya. Pengeluaran pemerintah dapat mempengaruhi aktivitas ekonomi dikarenakan pengeluaran pemerintah ini akan dapat menciptakan berbagai prasarana yang dibutuhkan dalam proses pembangunan. ${ }^{4}$ Pengeluaran pemerintah yang tercermin dalam Anggaran Pendapatan dan Belanja Daerah (APBD) bersumber dari bantuan pusat dan Pendapatan Asli Daerah (PAD).APBD ini merupakan bentuk dari akumulasi modal pemerintah yang digunakan untuk mendorong pertumbuhan ekonomi suatu daerah. Adapun sasaran penggunaan pengeluaran pemerintah

1 Mohammad Rizal Mubaroq dkk, "Pengaruh Investasi Pemerintah, Tenaga Kerja, dan Desentralisasi Fiskal Terhadap Pertumbuban Ekonomi Kabupaten Di Indonesia Tabun 2007 - 2010”, Jurnal M. Rizal M Met UNPAD, Januari 2013), hlm. 1

2 BPS Provinsi Jambi, Analisis Pertumbuhan Ekonomi Provinsi Jambi 2014, (Jambi, BPS Provinsi Jambi, 2014), hlm. 6

${ }^{3}$ Rozalinda, Ekonomi Islam Teori dan Aplikasinya pada Aktivitas Ekonomi, (Jakarta: Raja Grafindo Persada, 2014), hlm. 139

4 Moh.Arsjad Anwar dkk, Ekonomi Indonesia, Masalah dan prosfek 1989/1990, (Jakarta: Universitas Indonesia Press, 1989), hlm. 47 
adalah untuk membiayai pembangunan di bidang sarana dan prasarana yang dapat menunjang kelancaran usaha dan pemenuhan pelayanan masyarakat.

Selain dari pada pengeluaran pemerintah Investasi yang memadai juga akan berdampak positif terhadap kondisi perekonomian, karena dengan adanya investasi yang memadai maka modal akan tersedia, semakin banyak investor yang menanamkan modalnya tentunya akan meningkatkan produksi yang nantinya akan menghasilkan output yang tinggi, serta akan menambah pendapatan daerah dari pajak yang dibayarkan kepada pemerintah. Investasi merupakan keputusan mengeluarkan dana pada saat sekarang ini untuk membeli aktiva riil ataupun aktiva keuangan dengan tujuan untuk mendapatkan penghasilan yang lebih besar dimasa yang akan datang. ${ }^{5}$ Pembentukan modal dipandang sebagai pengeluaran yang akan menambah kesanggupan suatu perekonomian untuk menghasilkan barang, maupun sebagai pengeluaran yang akan menambah permintaan efektif seluruh masyarakat. ${ }^{6}$

Adapun Indikator mengenai pengaruh investasi dan pengeluaran pemerintah terhadap pertumbuhan ekonomi yang dibahas pada penelitian ini adalah sebagai berikut :

\section{Indikator Pengaruh Investasi dan Pengeluaran Pemerintah terhadap Pertumbuhan Ekonomi}

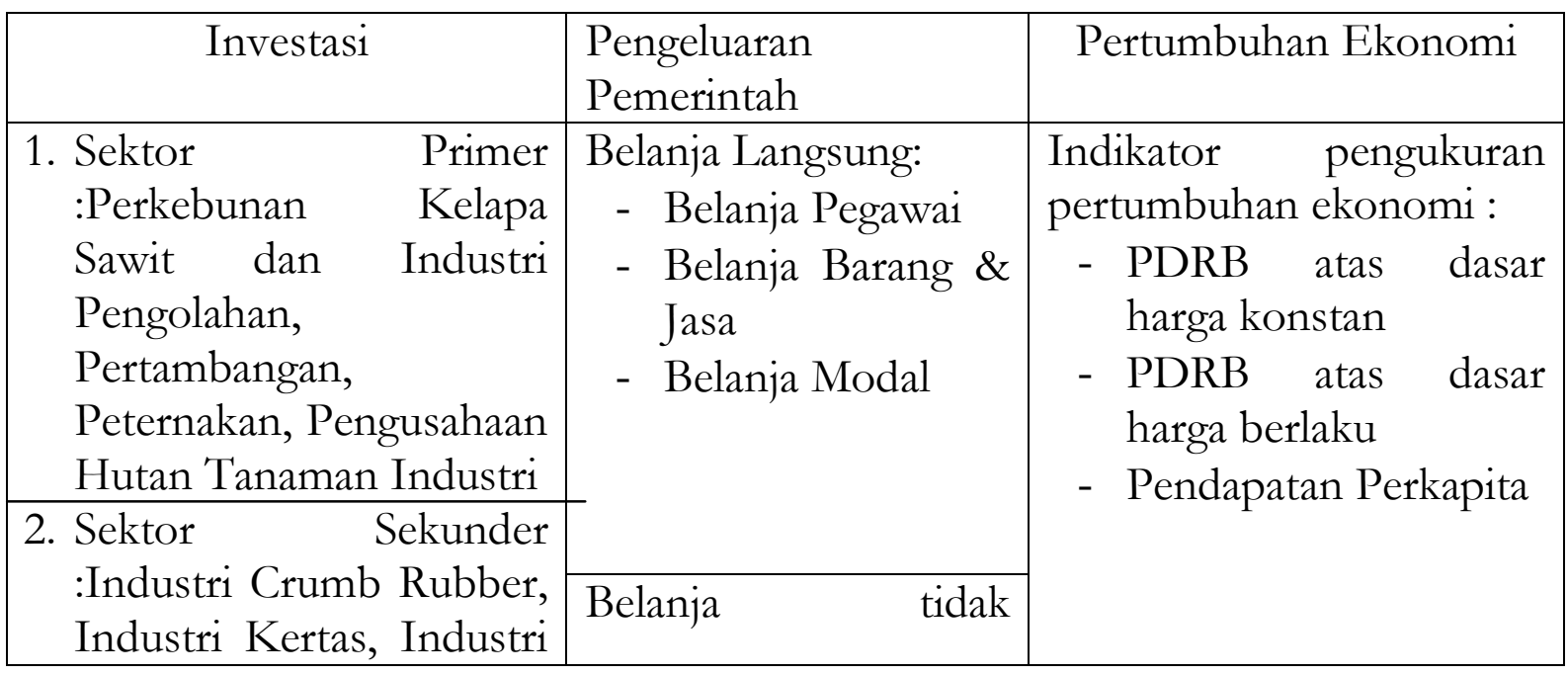
2010), hlm. 5

${ }^{5}$ Murdifin Haming \& Salim Basalamah, Studi Kelayakan Investasi Proyek \& Bisnis, Jakarta: Bumi Aksara,

${ }^{6}$ Sadono Sukirno, Ekonomi Pembangunan, (Jakarta: Kencana Prenadamedia Group, 2006), hlm. 257 


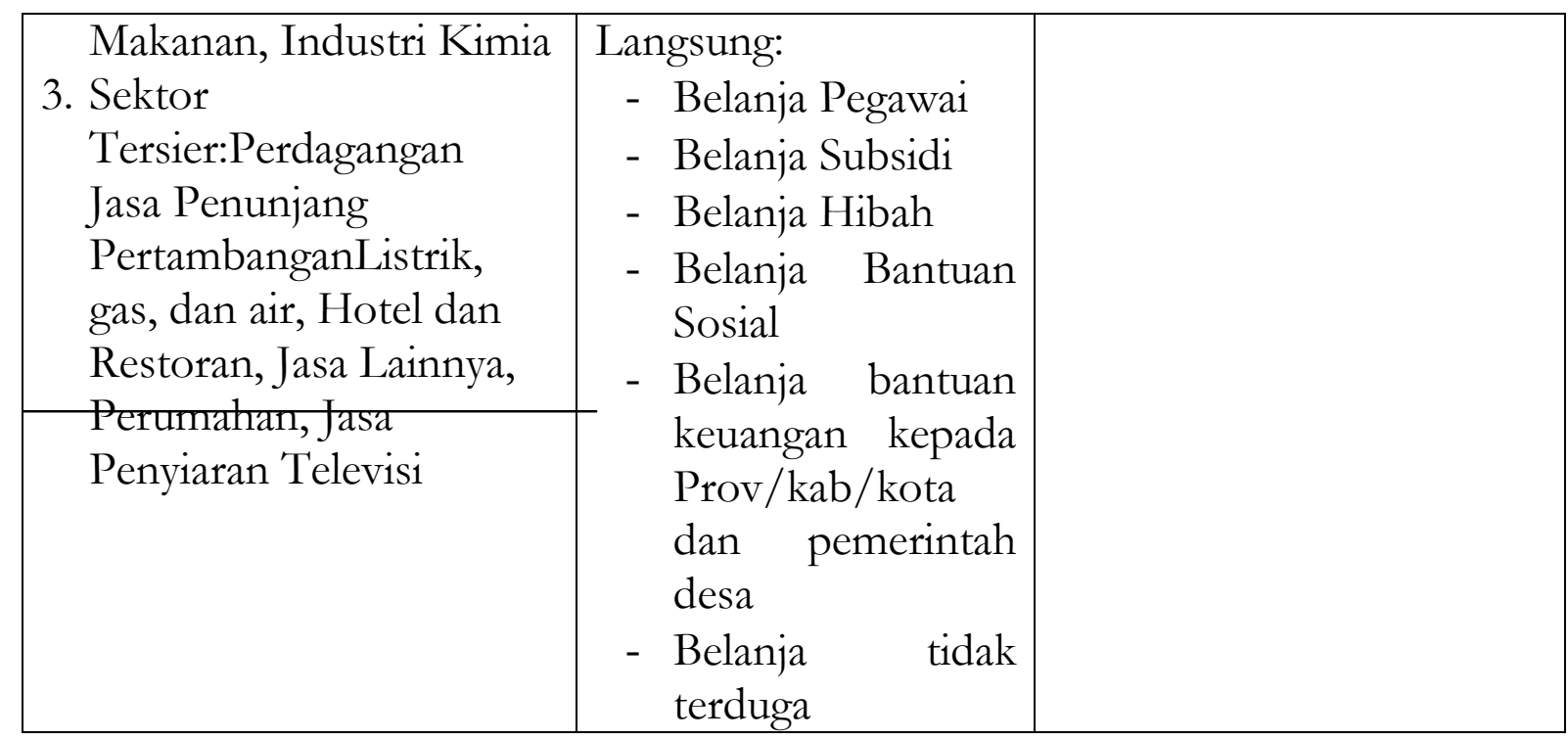

Sumber: BPS Provinsi Jambi \& BPMD

Untuk memberikan gambaran mengenai kondisi Investasi, Pengeluaran Pemerintah dan pertumbuhan ekonomi Provinsi Jambi, maka dapat dilihat dalam tabel berikut:

\section{Data Realisasi Investasi, Pengeluaran Pemerintah dan Pertumbuhan Ekonomi Provinsi Jambi}

\begin{tabular}{|c|c|c|c|c|}
\hline No & Tahun & Investasi & $\begin{array}{c}\text { Pengeluaran } \\
\text { Pemerintah }\end{array}$ & Pertumbuhan Ekonomi \\
\hline 1 & 2012 & $19.950 .000,00$ & $1.363 .636,00$ & 7,44 \\
\hline 2 & 2013 & $25.000 .000,00$ & $1.740 .363,00$ & 7,88 \\
\hline 3 & 2014 & $26.000 .000,00$ & $1.721 .517,00$ & 7,93 \\
\hline 4 & 2015 & $30.000 .000,00$ & $1.741 .503,00$ & 4,95 \\
\hline
\end{tabular}

Sumber: BPS Provinsi Jambi (data diolah)

Pada tabel tersebut terlihat bahwa realisasi investasi dari tahun 2012 hingga tahun 2015 terus mengalami peningkatan, yang artinya investor memiliki pandangan prospek yang baik terhadap keadaan investasi di Provinsi Jambi hingga banyak investor yang tertarik untuk melakukan penanaman modal atau berinvestasi di Provinsi Jambi. 
Pada tabel tersebut juga terlihat bahwa pengeluaran pemerintah pada tahun 2012 dan 2013 mengalami peningkatan, sedangkan ditahun 2014 pengeluaran pemerintah sedikit mengalami penurunan dari tahun sebelumnya, dan selanjutnya pengeluaran pemerintah kembali meningkat pada tahun 2015. Data Realisasi Pengeluaran pemerintah yang kami sajikan disini adalah pengeluaran pemerintah yang berupa belanja langsung, karena belanja langsung merupakan pengeluaran yang lebih menekankan aspek efisiensi dan efektifitas dalam penggunaannya. Semakin tingginya pengeluaran yang dilakukan pemerintah menunjukkan bahwa pemerintah terus berupaya untuk mensejahterakan rakyatnya dan untuk melakukan pembangunan agar kondisi perekonomian Provinsi Jambi semakin meningkat.

Sementara itu pada tabel juga terlihat bahwakondisi perekonomian Provinsi Jambi dari tahun 2012 hingga tahun 2015 berfluktuasi, pertumbuhan ekonomi dari tahun 2012 hingga tahun 2014 terus meningkat, dan peningkatan tertinggi adalah pada tahun 2014 yaitu sebesar 7,93 \% akan tetapi pertumbuhan ekonomi Provinsi Jambi kembali melemah pada tahun 2015.

Menurut Harrod dan Domar yang dikutip oleh Sayid syekh mengemukakan bahwa investasi merupakan pengeluaran yang mempengaruhi kegiatan ekonomi, maka investasi akan menambah jumlah barang modal didalam suatu masyarakat. ${ }^{7}$ Begitu pula Ibnu Khaldun mengatakan bahwasisi pengeluaran keuangan publik merupakan hal yang sangat penting, karena pengeluaran pemerintah memiliki peranan penting terhadap aktivitas ekonomi. Semakin banyak yang dibelanjakan oleh pemerintah, semakin baik akibatnya bagi perekonomian. ${ }^{8}$

Pada umumnya para ekonom sepakat kalau tingkat investasi berkorelasi positif dengan tingkat pertumbuhan ekonomi. Secara sederhana, tingkat investasi yang tinggi akan meningkatkan kapasitas produksi, yang pada akhirnya berujung pada peningkatan pendapatan masyarakat. Teori juga mengatakan bahwa kenaikan

7 Sayid Syekh, Sekilas Pengantar Ilmu Ekonomi dan Pengantar Ekonomi Islam, (Jakarta: GP Press Group, 2013), 8 Adiwarman Azwar Karim, Sejarah Pemikiran Ekonomi Islam, (Jakarta: Raja Grafindo Persada, 2012), hlm. 410 
investasi dapat mendorong terjadinya pertumbuhan ekonomi. ${ }^{9}$ Akan tetapi fakta yang terjadi di Provinsi Jambi menunjukkan bahwa pada saat investasi mengalami pertumbuhan yang tinggi, tidak langsung dapat mendorong pertumbuhan ekonomi, dan begitu pula sama halnya dengan pengeluaran pemerintah yang ketika mengalami peningkatan ternyata tidak secara langsung meningkatkan pertumbuhan ekonomi, begitu pula sebaliknya ketika investasi dan pengeluaran pemerintah menurun tidak langsung mengakibatkan kondisi pertumbuhan ekonomi melemah. Hal ini terbukti dengan adanya data investasi dan pengeluaran pemerintah yang mengalami peningkatan akan tetapi kondisi perekonomian Provinsi Jambi saat ini mulai melemah atau mengalami penurunan dari tahun sebelumnya.

\section{KERANGKA TEORI}

1. Investasi

Investasi berasal dari kata Invest yang berarti menanam atau menginvestasikan uang atau modal. ${ }^{10}$ Dalam pasal 1 ayat (1) Undang-undang nomor 25 tahun 2007 tentang penanaman modal disebutkan bahwa penanaman modal diartikan sebagai segala bentuk kegiatan penanaman modal, baik oleh penanam modal dalam negeri maupun penanam modal asing untuk melakukan usaha diwilayah negara Republik Indonesia.

Secara umum investasi atau penanaman modal dapat diartikan sebagai suatu kegiatan yang dilakukan baik oleh pihak pribadi (Natural Person) maupun badan hukum (Juridical Person) dalam upaya untuk meningkatkan dan/ atau mempertahankan nilai modalnya, baik yang berbentuk uang tunai (Cash Money), peralatan, aset tidak bergerak, hak atas kekayaan intelektual maupun keahlian. $^{11}$

\footnotetext{
${ }^{2}$ Efrizal Hasan, Syamsul Amar, Ali Anis, "Pengaruh Investasi, Angakatan kerja dan Pengeluaran Pemerintah terhadap Pertumbuhan Ekonomi diProvinsi Sumatra Barat”, hlm. 1

${ }^{10}$ Kamus lengkap 10 Milyar, Djamaries, (Jakarta: Citra Harta Prima) hlm. 171

11 Ana Rokhmatussa'dyah \& Suratman, Hukum Investasi \& Pasar Modal, (Jakarta: Sinar Grafika, 2011), hlm. 
Investasi berdasarkan pembiayaannya merupakan investasi yang didasarkan pada asal-usul investasi itu diperoleh. Investasi ini dibagi menjadi dua macam, yaitu :

1) Investasi yang bersumber dari modal asing (PMA), merupakan investasi yang bersumber dari pembiayaan luar negeri.

2) Investasi yang bersumber dari modal dalam negeri (PMDN), merupakan investasi yang bersumber dari pembiayaan dalam negeri. ${ }^{12}$

2. Pengeluaran Pemerintah

Pengeluaran pemerintah (goverment expenditure) adalah bagian dari kebijakan fiskal yaitu suatu tindakan pemerintah untuk mengatur jalannya perekonomian dengan cara menentukan besarnya penerimaan dan pengeluaran pemerintah setiap tahunnya, yang tercermin dalam dokumen Anggaran Pendapatan Belanja Negara (APBN) untuk nasional dan Anggaran Pendapatan Belanja Daerah (APBD) untuk daerah atau regional. Tujuan dari kebijakan fiskal ini adalah dalam rangka menstabilkan harga, tingkat output, maupun kesempatan kerja dan memacu atau mendorong pertumbuhan ekonomi. $^{13}$

Pengeluaran pemerintah adalah pengeluaran yang sifatnya habis dipakai dalam proses produksi setelah dikurangi dengan penjumlahan barang dan jasa yang dihasilkan oleh pemerintah, yang terdiri dari pembelian barang dan jasa (belanja barang), pembayaran balas jasa pegawai (belanja pegawai), dan penyusutan barang modal, dikurangi dengan hasil penjualan barang dan jasa (output pasar) pemerintah yang tidak dipisahkan dari kegiatan pemerintah. ${ }^{14}$

Adapun komponen pengeluaran pemerintah ini terbagi atas belanja langsung dan belanja tidak langsung, Belanja langsung adalah belanja yang terkait dengan produktivitas kegiatan atau langsung dengan tujuan organisasi,

\footnotetext{
${ }^{12}$ Salim dan Budi Sutrisno, Hukum Investasi di Indonesia, (Jakarta: Raja Grafindo Persada, 2008), hlm. 36-38

${ }^{13}$ Harry A. P. Sitaniapessy, "Pengaruh pengeluaran pemerintah terhadap PDRB dan PAD", Jurnal Economia, volume 9, nomor 1, (April 2013), hlm. 40

14 Badan Pusat Statistik Provinsi Jambi, Analisis Pertumbuban Ekonomi Provinsi Jambi 2013, Jambi: BPS Provinsi Jambi, 2013), hlm. 24
} 
misalnya belanja pegawai, honor yang merupakan sesuatu yang harus dibayarkan oleh pemerintah kepada pegawai tetapi apabila pegawai tidak melakukan pekerjaannya maka upah tidak akan dibayarkan. ${ }^{15}$

Berdasarkan Peraturan Menteri Dalam Negeri Nomor 13 Tahun 2006 Tentang Pedoman Pengelolaan Keuangan Daerah, mengenai belanja langsung yang terdapat dalam Pasal 50, Kelompok belanja langsung dari suatu kegiatan dibagi menurut jenis belanja yang terdiri dari belanja pegawai, belanja barang dan jasa serta belanja modal. ${ }^{16}$ Belanja tidak langsung adalah belanja yang secara tidak langsung terkait dengan produktivitas atau tujuan organisasi. pengeluaran tidak langsung meliputi: Belanja pegawai, belanja barang, subsidi daerah otonom, pembayaran bunga dan cicilan hutang serta pengeluaran rutin lainnya. ${ }^{17}$

\section{Pertumbuhan Ekonomi}

Pertumbuhan ekonomi adalah suatu ukuran kuantitatif yang menggambarkan perkembangan suatu perekonomian dalam suatu tahun tertentu apabila dibandingkan dengan tahun sebelumnya. ${ }^{18}$ Untuk menghitung tingkat pertumbuhan ekonomi akan selalu digunakan rumus:

$$
\mathrm{g}=\frac{\mathrm{GDP}_{1}-\mathrm{GDP}_{0}}{\mathrm{GDP}_{0}} 00
$$

\section{Keterangan:}

g adalah tingkat (persentase) pertumbuhan ekonomi

$\mathrm{GDP}_{1}$ adalah pendapatan nasional riil yaitu pendapatan nasional yang dihitung pada harga tetap yang dicapai dalam suatu tahun

$\mathrm{GDP}_{0}$ adalah pendapatan nasional riil pada tahun sebelumnya. ${ }^{19}$

\footnotetext{
${ }^{15} \mathrm{http}: / /$ ekaputralamury.blogspot.co.id/2012/12/perbedaan-belanja-pegawai-pada-belanja.html, akses tanggal 21 januari 2016, pukul: 11.04

16 muslimpoliticians.blogspot.co.id/2011/10/pengertian-pengertian-pada-struktur.html, akses tanggal 12 januari 2016, pukul 11.43

17 Moh.Arsjad Anwar dkk, Ekonomi Indonesia, Masalah dan prosfek 1989/1990, (Jakarta: Universitas Indonesia Press, 1989), hlm. 50

${ }^{18}$ Sadono Sukirno, Ekonomi Pembangunan, Edisi Kedua, (Jakarta: Prenadamedia Group, 2006), hlm. 9

${ }^{19}$ Sjahrir, Analisis Ekonomi Indonesia, (Jakarta: Gramedia Pustaka Utama, 1991), hlm. 50
} 


\section{HASIL PENELITIAN DAN PEMBAHASAN}

Penelitian ini diukur menggunakan metode penelitian kuantitatif deskriptif, yang secara deskriptif peneliti menjelaskan fenomena atau fakta yang ditemui penulis dengan cara menggambarkan data sekunder mengenai kondisi investasi, pengeluaran pemerintah dan pertumbuhan ekonomi Provinsi Jambi pada tahun yang bersangkutan dengan bantuan tabel, grafik ataupun diagram.

Sedangkan secara kuantitatif peneliti akan melakukan analisis statistik dengan menggunakan metode regresi linier berganda, pengujian statistik dan uji asumsi klasik yang akan menganalisis data sekunder yang telah diperoleh dari sumbernya dengan menggunakan bantuan perangkat lunak (Software). Dengan adanya pengujian ini akan diperoleh hasil mengenai pengaruh dan besaran pengaruh antara variabel investasi dan pengeluaran pemerintah terhadap variabel pertumbuhan ekonomi Provinsi Jambi.

Setelah dilakukan pengolahan data dengan menggunakan bantuan perangkat lunak (softwere) maka diperoleh hasil analisis regresi linier berganda sebagai berikut :

\section{Hasil Analisis Regresi Linier Berganda}

\begin{tabular}{|c|c|c|c|c|}
\hline Variable & Coefficient & Std. Error & t-Statistic & Prob. \\
\hline C & 7.416 .681 & 0.032554 & 2.278 .241 & 0.0000 \\
\hline LOG(INV?) & 0.095354 & 0.017309 & 5.509 .091 & 0.0000 \\
\hline LOG(GE?) & 0.003171 & 0.001414 & 2.243 .193 & 0.0330 \\
\hline
\end{tabular}

Sumber: Data diolah

Dari hasil output menggunakan softwere tersebut diperoleh persamaan sebagai berikut:

\section{$\log Y=\log 7.416 .681+\log 0.095354 * \operatorname{Inv}+\log 0.003171 * G E$}

Nilai koefisien dari masing-masing variabel dapat diartikan sebagai berikut :

1. Nilai konstanta (a) sebesar 7.416.681, artinya jika Investasi dan pengeluaran pemerintah $=0$ maka pertumbuhan ekonomi sebesar 7.416.681, dengan asumsi cateris paribus. 
2. Nilai koefisien elastisitas investasi sebesar 9,53\% yang memberikan arti bahwa setiap kenaikan nilai investasi sebesar $1 \%$ akan direspon oleh peningkatan pertumbuhan ekonomi sebesar 9,53\% dengan asumsi cateris paribus. Hasil ini sesuai dengan penelitian sebelumnya yang dilakukan oleh Efrizal hasan, Syamsul anwar dan Ali anis dalam jurnal yang berjudul pengaruh investasi, tenaga kerja dan pengeluaran pemerintah terhadap pertumbuhan ekonomi Provinsi Sumatra Barat.

3. Nilai koefisien elastisitas pengeluaran pemerintah sebesar 0,31 \% yang memberikan arti bahwa setiap kenaikan nilai pengeluaran pemerintah sebesar 1 \% akan direspon oleh peningkatan pertumbuhan ekonomi sebesar 0,31\% dengan asumsi cateris paribus. Hasil ini sesuai dengan temuan penelitian yang dilakukan oleh Sayekti Suindyah D dalam jurnalnya yang berjudul pengaruh investasi, tenaga kerja dan pengeluaran pemerintah terhadap pertumbuhan ekonomi Provinsi Jawa Timur.

Adapun untuk analisis dari masing-masing kabupaten/kota diperolah output sebagai berikut:

\section{Analisis Regresi Linier Berganda Perkabupaten}

\begin{tabular}{|l|l|}
\hline \multicolumn{2}{|c|}{ Fixed Effects (Cross) } \\
\hline _KERINCI_C & 0.005550 \\
_MERANGIN_C & 0.001824 \\
_SAROLANGUN_C & 0.001071 \\
_BATANGHARI-C & 0.000573 \\
_MUARAJAMBI-C & -0.001264 \\
_TANJABTIMUR_C & -0.001600 \\
_TANJABBARAT_C & -0.005707 \\
_TEBO_C & 0.001790 \\
_BUNGO_C & $4.86 \mathrm{E}-05$ \\
_KOTAJAMBI_C & -0.002286 \\
\hline
\end{tabular}

Sumber: Data diolah

Dari tabel tersebut dapat diketahui bahwa Investasi dan pengeluaran pemerintah memiliki pengaruh terhadap pertumbuhan ekonomi perkabupaten/kota diProvinsi Jambi dengan besaran pengaruh yang berbeda-beda. 
1. Nilai koefisien elastisitas untuk kabupaten Kerinci adalah sebesar 0,005550 artinya jika Investasi dan pengeluaran pemerintah $=0$ maka pertumbuhan ekonomi kabupaten Kerinciakan naik sebesar 0,55 \%, dengan asumsi cateris paribus.

2. Nilai koefisien elastisitas untuk kabupaten Merangin adalah sebesar 0,001824 artinya jika Investasi dan pengeluaran pemerintah $=0$ maka pertumbuhan ekonomi kabupaten Meranginakan naik sebesar 0,18\%, dengan asumsi cateris paribus.

3. Nilai koefisien elastisitas untuk kabupaten Sarolangun adalah sebesar 0,001071 artinya jika Investasi dan pengeluaran pemerintah $=0$ maka pertumbuhan ekonomi kabupaten Sarolangunakan naik sebesar 0,10\%, dengan asumsi cateris paribus.

4. Nilai koefisien elastisitas untuk kabupaten Batanghari adalah sebesar 0,000573 artinya jika Investasi dan pengeluaran pemerintah $=0$ maka pertumbuhan ekonomi kabupaten Batanghari akan naik sebesar 0,05 \%, dengan asumsi cateris paribus.

5. Nilai koefisien elastisitas untuk kabupaten Muaro Jambi adalah sebesar 0,001264 artinya jika Investasi dan pengeluaran pemerintah $=0$ maka pertumbuhan ekonomi kabupaten Muaro Jambi akan turun sebesar 0,12\%, dengan asumsi cateris paribus.

6. Nilai koefisien elastisitas untuk kabupaten Tanjab Timur adalah sebesar 0,001600 artinya jika Investasi dan pengeluaran pemerintah $=0$ maka pertumbuhan ekonomi kabupaten Tanjab Timur akan turun sebesar 0,16\%, dengan asumsi cateris paribus.

7. Nilai koefisien elastisitas untuk kabupaten Tanjab Barat adalah sebesar 0,005707 artinya jika Investasi dan pengeluaran pemerintah $=0$ maka pertumbuhan ekonomi kabupaten Tanjab Barat akan turun sebesar 0,57 \%, dengan asumsi cateris paribus. 
8. Nilai koefisien elastisitas untuk kabupaten Tebo adalah sebesar 0,001790 artinya jika Investasi dan pengeluaran pemerintah $=0$ maka pertumbuhan ekonomi kabupaten Tebo akan naik sebesar 0,17\%, dengan asumsi cateris paribus.

9. Nilai koefisien elastisitas untuk kabupaten Bungo adalah sebesar 4,8605 artinya jika Investasi dan pengeluaran pemerintah $=0$ maka pertumbuhan ekonomi kabupaten Bungo akan naik sebesar 4,86 \%, dengan asumsi cateris paribus.

10. Nilai koefisien elastisitas untuk Kota Jambi adalah sebesar -0,002286 artinya jika Investasi dan pengeluaran pemerintah $=0$ maka pertumbuhan ekonomi Kota Jambi akan turun sebesar 0,22\%, dengan asumsi cateris paribus.

Setelah dilakukan pengolahan data dari 10 kabupaten/kota tersebut dapat diketahui bahwa pertumbuhan ekonomi kabupaten/kota yang paling tinggi dipengaruhi oleh investasi dan pengeluaran pemerintah adalah kabupaten Tanjung Jabung Barat, Kota Jambi, Kabupaten Tanjung Jabung Timur dan Kabupaten Muaro Jambi.

Dalam penelitian dengan menggunakan data panel, harus dilakukan uji Hausman yang bertujuan untuk mengetahui apakah model pengaruh tetap atau model pengaruh acak. Statistik hasil uji Hausman dapat dilihat pada tabel berikut:

\section{Hasil Uji Hausman}

\begin{tabular}{|c|c|c|c|}
\hline Model & Chi-Square & $\begin{array}{c}\text { Chi-Square Tabel 5\% } \\
\mathrm{df}=2\end{array}$ & Prob. \\
\hline Fixed dan Random & 65,147 & 5,991 & 0,0000 \\
\hline
\end{tabular}

Sumber: Data diolah

Hasil uji Hausman memperoleh nilai $\mathrm{X}^{2}$ hitung $>\mathrm{X}^{2}$ tabel $(65,147>5,991)$ pada taraf signifikansi 5\% atau nilai $-\mathrm{p}$ hasil uji Hausman sebesar 0,000 $<0,05$. Sehingga dapat dinyatakan bahwa model yang menggambarkan pengaruh investasi dan pengeluaran pemerintah terhadap pertumbuhan ekonomi adalah model tetap (Fixed). Hasil uji mengindikasikan bahwa analisis data panel dengan pengaruh tetap 
lebih baik dibanding dengan model pengaruh acak. Adapun hasil uji perbandingan ketiga model tersebut adalah sebagai berikut:

\section{Perbandingan Model}

\begin{tabular}{|c|c|c|}
\hline Pooled OLS & Fixed Effect & Random Effect \\
\hline F hitung $=247,065$ & $\mathrm{~F}$ hitung $=481,688$ & $\begin{array}{l}\text { Hausman } \\
\text { Test }\left(\mathrm{X}^{2} \text { hitung) }\right. \\
65,147\end{array}$ \\
\hline $\mathrm{F}$ tabel $5 \%=3,32$ & $\mathrm{~F}$ tabel $5 \%=3,32$ & $\mathrm{X}^{2}$ tabel $=5,991$ \\
\hline $\begin{array}{l}\mathrm{F} \text { hitung }>\mathrm{F} \text { tabel } \\
\text { maka signifikan }\end{array}$ & $\begin{array}{l}\mathrm{F} \text { hitung }>\mathrm{F} \text { tabel } \\
\text { maka signifikan }\end{array}$ & $\begin{array}{l}\mathrm{X}^{2} \text { hitung } \\
\mathrm{X}^{2} \text { tabel } \\
\text { signifikan }\end{array}$ \\
\hline \multicolumn{2}{|c|}{$\begin{array}{l}\text { Hasil uji Chow test antara Pooled OLS dengan } \\
\text { Fixed Effect }: \mathrm{F} \text { hitung }=481,688 \\
\mathrm{~F} \text { tabel } 5 \%=3,32 \\
\mathrm{~F} \text { hitung }>\mathrm{F} \text { tabel maka signifikan artinya } \\
\text { estimasi model dengan menggunakan fixed effect } \\
\text { lebih baik dibandingkan dengan pooled OLS. }\end{array}$} & $\begin{array}{l}\text { Fixed Effect lebih } \\
\text { baik dari Random } \\
\text { Effect }\end{array}$ \\
\hline
\end{tabular}

Sumber: Data diolah

Setelah dilakukan uji asumsi klasik terhadap data-data yang telah dikumpulkan maka diperoleh hasil output sebagai berikut:

1. Uji Normalitas

Uji normalitas digunakan untuk mengetahui apakah dalam penelitian berdistribusi normal atau tidak. ${ }^{20}$ Dasar pengambilan keputusannya adalah nilai Jarque Bera (JB) yang diperoleh harus lebih kecil dari nilai $\mathrm{X}^{2}$ tabel.

Setelah dilakukan pengujian pada data, maka diperoleh nilai Jarque Bera (JB) yang lebih kecil dari nilai $\mathrm{X}^{2}$ tabel $(0,293<5,991)$, maka dapat disimpulkan bahwa residual berdistribusi normal.

2. Uji Heteroskedastisitas

Pada uji Heteroskedastisitas diperoleh hasil p value obs*-Square atau biasa disebut $\mathrm{X}^{2}$ tabelyang lebih besar daria. Yaitu 5,991 > 0,05, artinya dengan tingkat keyakinan 95\% model regresi ini dikatakan bebas gejala

20 Steffi Sigilipu, "Pengarub Penerapan Informasi Akuntansi Manajemen dan Sistem Pengukuran Kinerja Terbadap Kinerja Manajerial”, Jurnal EMBA Vol. 1 No. 3 (Juni 2013), hlm. 244 
heteroskedastisitas. Dengan demikian pada data investasi dan pengeluaran pemerintah tidak terdapat gejala heteroskedastisitas.

3. Uji Multikolinieritas

Tahapan pengujian dengan pendekatan korelasi parsial dengan tahapan sebagai berikut :

a. Persamaan Regresi:

$$
\log Y=\log a_{0}+\log * \operatorname{Inv}+\log * G E
$$

b. Estimasi Regresi :

$$
\begin{aligned}
& \mathrm{X} 1=\mathrm{b}_{0}+\log * \mathrm{GE} \\
& \mathrm{X} 2=\mathrm{b}_{0}+\log * \mathrm{INV}
\end{aligned}
$$

Untuk persamaan (1) nilai $\mathrm{R}^{2}$ adalah sebesar 0,4925 selanjutnya disebut $\mathrm{R}_{1}^{2}$ Untuk persamaan (2) nilai $\mathrm{R}^{2}$ adalah sebesar 0,9900 selanjutnya disebut $\mathrm{R}_{11}^{2}$ Untuk persamaan (3) nilai $\mathrm{R}^{2}$ adalah sebesar 0,9895 selanjutnya disebut $\mathrm{R}_{12}^{2}$ Diketahui bahwa nilai $\mathrm{R}_{1}^{2}<\mathrm{R}^{2}{ }_{11}, \mathrm{R}^{2}{ }_{12}(0,4925<0,9900,0,9895)$ artinya model ini tidak mengandung gejala multikolinieritas.

4. Uji Autokorelasi

Uji ini untuk melihat terjadinya anggota-anggota dari serangkaian pengamatan yang tersusun dalam rangkaian waktu. Uji autokorelasi dilihat melalui nilai Durbin-Watson. Nilai DW yang diperoleh adalah sebesar 1, 776.Nilai du dengan $\mathrm{k}=2$ dan $\mathrm{n}=40$ adalah 1,600, sedangkan nilai 4-du (41,600) adalah 2,400, sehingga klasifikasi nilai DW berada pada interval yaitu $1,600<1,776<2,400$ hal inimenunjukkan bahwa pada model regresi ini tidak terdapat gejala autokorelasi.

Setelah dilakukan uji statistik terhadap data penelitian, maka diperoleh hasil sebagai berikut:

1. Koefisien Determinasi $\left(\mathrm{R}^{2}\right)$

Koefisien determinasi $\left(\mathrm{R}^{2}\right)$ bertujuan mengukur seberapa jauh kemampuan model dalam menerangkan variasi variabel terikat. Dalam penelitian ini koefisien 
determinasi untuk mengukur seberapa jauh kemampuan variabel bebas (investasi dan pengeluaran pemerintah) menjelaskan variabel terikat (pertumbuhan ekonomi Provinsi Jambi).

Nilai Koefisien determinasi $\left(\mathrm{R}^{2}\right)$ dari hasil regresi linier berganda adalah sebesar 0,492. Artinya 49,2\% keragaman investasi dan pengeluaran pemerintah mempengaruhi keragaman tingkat pertumbuhan ekonomi Provinsi Jambi. Sedangkan sisanya sebesar 50,8 \% dipengaruhi oleh keragaman lain, yang tidak disebutkan dalam model ini.

2. Uji Parsial (Uji T)

Uji parsial dengan alpha $=5 \%$ dan derajat kebebasan n-k-1 (40-2-1) diperoleh t tabel sebesar 2,042. Dari hasil perhitungan dengan regresi linier berganda untuk pengujian pengaruh investasi terhadap pertumbuhan ekonomi diperoleh nilai koefisien regresi parsial $=0,095354$ sedangkan standar error diperoleh $=0,017309$, sehingga diperoleh nilai t hitung sebesar 5,509 dengan $\mathrm{p}=0,000$. Nilai t tabel pada taraf signifikansi $5 \%$ adalah 2,042. Dikarenakan nilai $\mathrm{t}$ hitung $>\mathrm{t}$ tabel $(5,509>2,042)$ artinya Investasi secara parsial berpengaruh signifikan terhadap pertumbuhan ekonomi Provinsi Jambi.

Sedangkan dari hasil perhitungan regresi linier berganda untuk pengujian pengaruh pengeluaran pemerintah terhadap pertumbuhan ekonomi diperoleh nilai koefisien regresi parsial $=0,003171$ sedangkan standar error diperoleh $=$ 0,001414, sehingga diperoleh nilai $t$ hitung sebesar 2,243 dengan $p=0,033$. Nilai t tabel pada taraf signifikansi $5 \%$ adalah 2,042. Dikarenakan nilai t hitung $>\mathrm{t}$ tabel $(2,243>2,024)$ artinya pengeluaran pemerintah secara parsial berpengaruh signifikan terhadap pertumbuhan ekonomi Provinsi Jambi.

3. Uji Simultan (Uji F)

Uji simultan dengan alpha $=5 \%$ dan derajat kebebasan $(\mathrm{k}, \mathrm{N}-\mathrm{k}-1)$ maka (2, 40-2-1) sehingga diperoleh F tabel sebesar 3,32.

Dari hasil perhitungan diperoleh nilai F hitung sebesar 247,065 dengan $\mathrm{p}=0,026$. Dikarekan $\mathrm{F}$ hitung $>\mathrm{F}$ tabel $(247,065>3,32)$ artinya investasi dan 
pengeluaran pemerintah secara bersama-sama (simultan) berpengaruh terhadap pertumbuhan ekonomi Provinsi Jambi.

Setelah dilakukan pengujian pada data yang dikumpulkan maka diperoleh hasil bahwa dalam pengujian secara parsial investasi sebagai variabel X1 berpengaruh signifikan terhadap pertumbuhan ekonomi hal ini menunjukkan bahwa investasi yang selalu meningkat tiap tahunnya telah mampu menopang pertumbuhan ekonomi, akan tetapi investasi di Provinsi Jambi masih harus ditingkatkan karena pada data investasi perkabupaten diprovinsi Jambi terlihat penanaman investasi yang dilakukan belum merata keseluruh kabupaten, penanaman modal yang dilakukan investor hanya ada pada beberapa kabupaten seperti Tanjung Jabung Barat, Muaro Jambi dan Muaro Bungo sementara pada kabupaten Kerinci dan Muaro Tebo investasi terlihat belum memadai.

Begitupula dengan pengeluaran pemerintah pada 9 kabupaten dan 1 kota di Provinsi Jambi yang setiap tahun mengalami peningkatan, hasil yang diperoleh adalah pengeluaran pemerintah berpengaruh positif yang signifikan terhadap pertumbuhan ekonomi Provinsi Jambi, artinya pengeluaran pemerintah telah dapat berkontribusi terhadap kondisi pertumbuhan ekonomi. Pengeluaran pemerintah yang selalu berusaha ditingkatkan pemerintah dengan tetap memperhatikan aspek efisiensinya, yang berupa belanja langsung dapat memicu meningkatnya kesejahteraan masyarakat, salah satunya dengan pembayaran gaji pegawai dengan demikian pendapatan perkapita masyarakat akan meningkat dan hal ini akan meningkatkan pertumbuhan ekonomi.

\section{KESIMPULAN}

Setelah melakukan uji asumsi klasik maupun uji statistik dengan menggunakan metode regresi linier berganda dan menganalisis data sekunder mengenai pengaruh investasi dan pengeluaran pemerintah terhadap pertumbuhan ekonomi Provinsi Jambi dari tahun 2012-2015, maka dapat disimpulkan bahwa : 
a). Pengaruh Investasi terhadap Pertumbuhan Ekonomi Provinsi Jambi.

Analisis mengenai pengaruh investasi terhadap pertumbuhan ekonomi Provinsi Jambi menunjukkan hasil yang positif signifikan, sebagaimana ditunjukkan pada besaran pengaruh yang ditimbulkan oleh variabel Investasi, Nilai koefisien elastisitasnya sebesar 0,0953 jika Investasi mengalami kenaikan $1 \%$ maka pertumbuhan ekonomi yang ditunjukkan dengan PDRB berdasarkan harga konstan tahun 2000 akan naik sebesar 9,53\% dengan asumsi cateris paribus atau variabel yang lain dianggap tetap.

b).Pengaruh pengeluaran pemerintah terhadap Pertumbuhan Ekonomi Provinsi Jambi dalam analisis mengenai pengaruh pengeluaran pemerintah terhadap pertumbuhan ekonomi Provinsi Jambi menunjukkan hasil yang positif signifikan. Diperoleh hasil koefisien elastisitas sebesar 0,031, artinya jika pengeluaran pemerintah mengalami kenaikan $1 \%$ maka pertumbuhan ekonomi akan naik sebesar 0,31\% dengan asumsi cateris paribus atau variabel yang lain dianggap tetap.

c). Pengaruh Investasi dan Pengeluaran pemerintah terhadap pertumbuhan ekonomi Provinsi Jambi. Dari hasil analisis yang dilakukan diperoleh nilai konstanta sebesar 7.416.681 artinya, jika investasi dan pengeluaran pemerintah = 0 maka tingkat pertumbuhan ekonomi yang ditunjukkan dengan PDRB atas dasar harga konstan tahun 2000 adalah sebesar 7.416.681,- dengan asumsi cateris paribus atau variabel lain dianggap tetap. Setelah dilakukan uji $\mathrm{f}$ (uji simultan) diperoleh nilai signifikan 0,026 yang lebih kecil dari taraf keyakinan 0,05, yang artinya investasi dan pengeluaran pemerintah secara simultan (bersama-sama) berpengaruh signifikan terhadap pertumbuhan ekonomi Provinsi Jambi.

d). $R$ square yang diperoleh adalah sebesar 0,492 yang berarti bahwa 49,2\% keragaman investasi dan Pengeluaran pemerintah mempengaruhi keragaman tingkat pertumbuhan ekonomi Provinsi Jambi. Sedangkan sisanya sebesar 50,8 \% dipengaruhi oleh keragaman lain, yang tidak disebutkan dalam model ini. 


\section{DAFTAR PUSTAKA}

Alim dan Budi Sutrisno, Hukum Investasi di Indonesia, Jakarta: Raja Grafindo Persada, 2008

Ana Rokhmatussa'dyah \& Suratman, Hukum Investasi \& Pasar Modal, Jakarta: Sinar Grafika, 2011

Adi Raharjo, "Pengaruh Pengeluaran Pemerintah, investasi swasta dan angkatan kerja terhadap pertumbuhan ekonomi tahun 1982-2003 (studi kasus dikota Semarang)", Tesis Universitas Diponegoro Semarang, (2006)

Anton Hermanto Gunawan, Anggaran Pemerintah dan Inflasi di Indonesia, Jakarta: Gramedia Pustaka Utama, 1991

Arsjad Anwar dkk, Ekonomi Indonesia, Masalah dan prosfek 1989/1990, Jakarta: Universitas Indonesia Press, 1989

Badan Pusat Statistik Provinsi Jambi, Analisis Pertumbuhan Ekonomi Provinsi Jambi 2013, Jambi: BPS Provinsi Jambi, 2013

Bambang Juanda, Ekonometrika Pemodelan dan Pendugaan, Bogor: IPB Press, 2009

Burhan Bungin, Metode Penelitian Sosial dan Ekonomi, Jakarta: Kencana, 2013

BPS Provinsi Jambi, Jambi dalam angka Tahun 2012, Jambi: BPS Provinsi Jambi, 2012

BPS, Statistik Daerah Provinsi Jambi 2013, Jambi, BPS Provinsi Jambi, 2013

BPS Provinsi Jambi, Jambi dalam angka Tahun 2014, Jambi: BPS Provinsi Jambi, 2014

BPS Provinsi Jambi, Analisis Pertumbuhan Ekonomi Provinsi Jambi 2014, Jambi, BPS Provinsi Jambi, 2014

Djamaries, Kamus lengkap 10 Milyar, Jakarta: Citra Harta Prima

Digilib.uinsuska.ac.id/8212/1/BAB\%201,\%20V,\%20DAFTAR\%PUSTAKA.pdf.

Akses tanggal 09 Nopember 2015, pukul 14.35

Efrizal Hasan, Syamsul Amar, Ali Anis, "Pengarub Investasi, Angakatan kerja dan Pengeluaran Pemerintah terhadap Pertumbuhan Ekonomi diProvinsi Sumatra Barat". 
Harry A. P. Sitaniapessy, "Pengaruh pengeluaran pemerintah terhadap PDRB dan PAD”, Jurnal Economia, volume 9, nomor 1, (April 2013) http://ekaputralamury.blogspot.co.id/2012/12/perbedaan-belanja-pegawai-padabelanja.html, akses tanggal 21 januari 2016, pukul: 11.04 http://www.stiualhikmah.ac.id/index.php/kecerdasan-finansial/188-investasi-

dalam-pandangan-al-qur-an-sunnah, akses tanggal 1106 2016, pukul 14.34 Jhingan, Ekonomi Pembangunan dan Perencanaan, Jakarta: Rajawali Press, 2012

Lailahamkha.blogspot.co.id, Akses tanggal 9 juni 2016, pukul 05.43

Murdifin Haming \& Salim Basalamah, Studi Kelayakan Investasi Proyek \& Bisnis,Jakarta: Bumi Aksara, 2010

Michael P. Todaro \& Stephen C. Smith, Pembangunan Ekonomi, Edisi Kesembilan, Indonesia, PT. Gelora Aksara Pratama, 2006

Mohammad Rizal Mubaroq dkk, "Pengaruh Investasi Pemerintah, Tenaga Kerja, dan Desentralisasi Fiskal Terbadap Pertumbuhan Ekonomi Kabupaten Di Indonesia Tabun 2007 - 2010”, Jurnal M. Rizal M Met UNPAD, (Januari 2013)

Muslimpoliticians.blogspot.co.id/2011/10/pengertian-pengertian-padastruktur.html, akses tanggal 12 januari 2016, pukul 11.43.

Peraturan Daerah Provinsi Jambi Nomor 2 Tahun 2009

Richard T. Gill, Ekonomi Pembangunan Dulu dan Sekarang, Jakarta: Ghalia Indonesia, 1983

Rosmawati Sinuraya, "Analisis Pengaruh Pengeluaran Pemerintah terhadap pertumbuhan ekonomi kabupaten Karo", Skripsi Universitas Sumatra Utara, (2010)

Rencana Pembangunan Jangka Panjang Daerah Provinsi Jambi Tahun 2005-2025

Rencana Pembangunan Jangka Menengah Provinsi Jambi tahun 2011-2015

Sadono Sukirno, Ekonomi Pembangunan, Edisi Kedua, Jakarta: Prenada Media Group, 2006

Sadono Sukirno, Makro Ekonomi Modern, Jakarta: Raja Grafindo Persada, 2007

Sadono Sukirno, Pengantar Ekonomi Makro, Jakarta: Graha Media, 2010

Sayid Syekh, Pengantar Makro Ekonomi, Jakarta: Gaung Persada Press Group, 2014 
Sayid Syekh, Sekilas Pengantar Ilmu Ekonomi dan Pengantar Ekonomi Islam, Jakarta: GP Press Group, 2013

Sjahrir, Analisis Ekonomi Indonesia, Jakarta: Gramedia Pustaka Utama, 1991

Sayekti Suindyah D, "Pengaruh Investasi, tenaga Kerja dan Pengeluaran pemerintah terhadap pertumbuhan ekonomi diprovinsi jawa timur, 2009”, Tesis Universitas Darul 'Ulum Jombang (2009)

Steffi Sigilipu, "Pengaruh Penerapan Informasi Akuntansi Manajemen dan Sistem Pengukuran Kinerja Terhadap Kinerja Manajerial”, Jurnal EMBA Vol. 1 No. 3 (Juni 2013)

Tim Penyusun, Pedoman Penulisan Skripsi, Jambi: Syariah press, 2014

Unit Statistik, Survey dan Liaison, Statistik Ekonomi Kenangan Daerah, Jambi: Bank Indonesia, 2015

Usman Husaini \& Purnomo Setiady akbar, Pengantar Statistika, Edisi Kedua Jakarta: Bumi Aksara, 2012

W. Riawan Tjandra, Hukum Keuangan Negara, Jakarta: Grasindo, 2006. 